\title{
ЭВОЛЮЦИЯ ПАРАДИГМ НАСЛЕДОВАНИЯ И РАЗВИТИЯ И ИХ ВЕДУЩАЯ РОЛЬ В СОЗДАНИИ ИННОВАЦИОННЫХ СЕЛЕКЦИОННЫХ ТЕХНОЛОГИЙ \\ В.А. Драгавцев ${ }^{1}$, С.И. Малецкий ${ }^{2}$ \\ ${ }^{1}$ Агрофизический научно-исследовательский институт, Санкт-Петербург, Россия; \\ ${ }^{2}$ Институт цитологии и генетики СО РАН, Новосибирск, Россия \\ Эл.noчma: ${ }^{1}$ dravial@mail.ru; ${ }^{2}$ stas@bionet.nsc.ru \\ Статья поступила в редакиию 07.09.2014; принята к печати 21.05.2015
}

В обзоре показана возрастающая роль эпигенетической парадигмы для формирования новых представлений о наследственности, генотипической изменчивости и развитии организмов и ее значение в создании инновационных технологий селекции. Дан анализ истории смены парадигм в учении о наследственности. Описано обнаружение нового важного феномена эпигенетической организации количественных признаков - смены спектра продуктов генов под одним и тем же признаком при смене лимитирующего фактора внешней среды - и показаны расшифрованные механизмы этого феномена. Новое знание о природе и механизмах эколого-генетического «устройства» компонентов продуктивности позволяет прогнозировать эффекты взаимодействия «генотип-среда», появление трансгрессий и экологически зависимого гетерозиса, сдвиги доминирования количественных признаков и сдвиги знаков и величин генотипических корреляций в разных средах и другие характеристики, необхдимые для быстрого и эффективного конструирования новых сортов с высокой продуктивностью, устойчивостью и качеством продукции.

Ключевые слова: менделизм, парадигма, наследование, развитие, пелоризм, количественный признак, эпигенетика, полигены, локусы количественных признаков.

\section{THE EVOLUTION OF PARADIGMS OF HEREDITY AND DEVELOPMENT AND THEIR LEADING ROLE IN DESIGNING OF INNOVATIVE BREEDING TECHNOLOGIES V.A. Dragavtsev ${ }^{1}$, S.I. Maletskiy ${ }^{2}$ \\ ${ }^{1}$ Agrophysical Research Institute, Saint Petersburg, Russia; \\ ${ }^{2}$ Institute of Cytology and Genetics of the Siberian Branch of the Russian Academy of Sciences, Novosibirsk, Russia \\ E-mail: ${ }^{1}$ dravial@mail.ru; ${ }^{2}$ stas@bionet.nsc.ru}

The increasing role of the epigenetic paradigm in developing new concepts in the fields of heredity, development and genotypic variability of organisms and its significance for designing new breeding technologies is shown. An analysis of the history of paradigm changes in the science of heredity is presented. A new important phenomenon of the epigenetic organization of quantitative characters - changes in the spectrum of genes controlling a defined character upon changes in a limiting factor of the environment - is described. This new idea about the nature of eco-genetic "design" of productivity components allows predicting the effects of interactions between genotypes and their environments, the appearance of transgressions, the ecologically dependent heterosis, the displacements of quantitative character dominance, the sings and levels of genotypic correlations in different environments, and other quantitative characteristics of importance for smart and effective engineering of new crop varieties having high productivity, steadiness and quality.

Keywords: mendelism, paradigms of inheritance and development, pelorism, eco-genetic nature of quantitative characters, epigenetics, polygens, QTL.

«Я, конечно, знаю, что вся генетика основана на предположении о высокой точности и воспроизводимости действия генов. Такое ложное предположение могло возникнуть из-за того, что нет никаких доказательств, подтверждающих, что в генетических экспериментах измеряется первичное действие генов».

(Г. Кэксер [33], С. 61)

«К сожалению, у современных генетиков нет мостов с практической селекиией».

(М.В. Келдыии [28], С. 63) 


\section{ВВЕДЕНИЕ}

\section{Основные парадигмы наследования и развития}

«Парадигма устанавливает те первичные отношения, в соответствии с которыми формулируются аксиомы, определяются понятия, протекают размышления и строятся теории» [2]. «Смены парадигм - это исторические революции в науке» [32].

В XIX и XX вв. в истории биологии происходила смена парадигм, выражающих представления о природе биологических процессов, лежащих в основе наследственности, изменчивости и развития организмов. До появления генетики существовали организмоцентрическая (ОЦП) и видоцентрическая (ВЦП) парадигмы. В ХХ в. к ним добавились геноцентрическая (ГЦП) и эпигенетическая (ЭГП). Особо выделим биосфероцентрическую парадигму жизни (БЦПж) В.И. Вернадского [39]. Названные парадигмальные установки - комплексные концепции, они не являются полностью взаимоисключающими, но каждая из них позволяет давать одним и тем же явлениям и процессам природы свои интерпретации. Они акцентируют внимание на тех или иных представлениях о предмете, которые складывались в прошлом и складываются сейчас в научном сознании естествоиспытателя. Так, «согласно ОЦП, наследственность - это воспроизводство потомками признаков родителей (“"подобное порождает подобное”), то есть наследственность рассматривалась как последовательность в череде поколений онтогенетических процессов, формирующих во времени ткани, органы и другие структуры, из которых состоит целостный организм. В рамках ОЦП наследственность - это слитное свойство, присущее организму как целому, а не отдельным его частям» [39].

Роль геометрических представлений в духе В.И. Вернадского в понимании процесса морфогенеза излагает в своих публикациях один из пионеров эпигенетики К. Уоддингтон [57]. Он уподобил динамику онтогенеза эпигенетическому ландшафту, то есть набору траекторий, ведущих развивающийся организм от начального состояния к взрослому. Эпигенетический ландшафт состоит из формирующихся на его поверхности траекторий, образующих систему параллельных углубляющихся желобов, которые получили преимущество в развитии и обозначены Уоддингтоном как креоды. Онтогенез (и морфогенез) по Уоддингтону основан на геометрических представлениях - эпигенетический ландшафт, эпигенетические траектории, креоды.

Эволюция взглядов на единицы наследственности

Наука о наследственности за прошедшее с конца XIX в. время постоянно претерпевала изменения, создавая все новые и новые модели знаний о наследовании и развитии. Первоначально на смену парадигме о слитной наследственности, принятой в XIX в., пришел менделизм, то есть сформулированные Г. Менделем законы наследования, и в научный оборот было введено понятие «наследственный фактор». Основа менделизма - исследование в гибридологических экспериментах поведения дискретных признаков, контролируемых отдельными факторами. В 1909 г. Иоганнсен заменил термин «наследственный фактор» более лаконичным - «ген». «Термин ген - это своего рода математическая характеристика открытых в экспериментах по скрещиванию реаль- но существующих, независимых, комбинирующихся и расщепляющихся единиц наследственности неизвестной природы, но оказывающих определенное действие» (Ригер и др. [46], с. 66). Ген рассматривался как основная абстрактная физическая и функциональная «единица наследственности» в течение всей первой половины ХХ в.

Менделевскую сегрегацию по факторам наследственности можно наблюдать не только по признакам, контролируемым отдельными генами (отрезками ДНК), но по более крупным геномным структурам. Это могут быть: а) отдельные локусы хромосом, одновременно включающие как совокупности регуляторных, так и структурных сайтов; б) суперлокусы-крупные участки хромосом, детерминирующие развитие сложных признаков цветка (например, гетеростилия цветков), локусы таксономических количественных признаков; в) признаки, контролируемые отдельными хромосомами (например, хромосомная детерминация пола цветков, Richards: [87]); г) сегрегация по целым геномам у энотер (Cleland: [75]) и др.

В ходе исторического развития теории Менделя и хромосомной теории наследственности в XX в., а также с открытием химического кода молекул ДНК и РНК наследственность стали определять уже не как совокупность менделевских факторов неизвестной природы, а как совокупность локализованных в хромосомах реальных генов, представленных нуклеотидными последовательностями. Итог подобной эволюции представлений о наследственности - геноцентрическая парадигма (ГЦП), согласно которой сходство особей разных поколений обязано тому, что любые признаки организмов детерминированы генами ядра и цитоплазмы. Другими словами, нуклеотидные последовательности ДНК и РНК содержат информацию, полностью детерминирующую генотипические средние величины и генотипическую изменчивость признаков. Из этих преформистских представлений следует, что, изучая структуру геномов и генетический контроль различных метаболических реакций в клетках, можно прогнозировать наследование и развитие любых признаков организма.

\section{Эпигенетика}

В последнее время бурно развивается ЭГП (эпигенетическая парадигма), отрицающая и дополняющая многие базовые положения ГЦП. Так Томас и др. [93] показали, что многие факты современной физиологии растений несовместимы с ГЦП. Хард обрисовал наступающую эру эпигенетики [82]. Продолжается критика редукционизма $[85,88,91]$, показана эпигенетическая феноменология у условных доминантных мутантов дрозофилы [60], продолжает развиваться синергетика [58], показаны эпигенетические феномены, определяющие сложные свойства организмов [89], выдвинута гипотеза о механизме инициации малыми РНК метилирования ДНК de novo и аллельного исключения [11].

\section{Век эпигенетики - век ЭГП}

«Только со смертью догмы начинается наука». (Г. Галилей)

Многие биологи называют XXI в. веком эпигенетики. Б.Ф. Ванюшин [9] подчеркивает: «Нельзя забывать, что у организмов существуют мощные ре- 
гуляторные элементы (в геноме и на уровне клетки), которые контролируют работу генов. Эти сигналы накладываются на генетику и часто по-своему решают “быть или не быть”». Даже самая отличная генетика может вовсе не реализоваться, если эпигенетика будет неблагополучной. По образному выражению П. и Д. Медаваров «генетика предполагает, а эпигенетика располагает».

К концу ХХ в. генетикам были известны следующие эпигенетические механизмы: метилирование ДНК и ацетилирование гистонов, приводящие к наследованию эпигенетических феноменов (генотрофы А. Даррента [79], никотинотрофы Е. Богдановой [6] и т. п.). Были известны и другие эпигенетические феномены: дифференциальная активность генов в онтогенезе [29], длительные модификации [16], генетическая ассимиляция [6], миксоплоидия [68], парамутации [65], родительский импринтинг, эпигенетическая детерминация пола, инактивация Xхромосомы [12], наследование белков-прионов [27], «сигнальная наследственность» [36]. В 2004 г. открыты эпигенетические механизмы яровизации [71, 90], в 2012 г. - эпигенетические механизмы моногамии степных полевок [59].

Поучительны исторические факты обнаружения эпигенетических феноменов. Так в 1742 г. студентом из шведского города Упсалы М. Сёбергом на одном из островов недалеко от Стокгольма были найдены в диких зарослях льнянки обыкновенной растения с радиально симметричными цветками, которые имели пять пыльников вместо четырех и пять шпорцев вместо одного (см. рис.).

Профессор Сёберга К. Линней, увидев эти растения в гербарии, был настолько поражен, что поначалу заподозрил подделку (студенческую шутку). Тщательная проверка показала, что это были именно льнянки, но с нестандартной морфологией и симметрией цветков. К. Линней назвал эту форму льнянки Peloria (по гречески - «Монстр») и добавил: «Не может быть ничего более фантастического, чем то, что произошло здесь: растение, которое всегда давало неправильные (зигоморфные) цветки, вдруг произвело сильно отклоняющееся потомство с правильными цветками. По этому признаку оно отличается от всех своих свойств и от всего класса. Это явление не сравнимо ни с чем в ботанике» (цит. по: Густафссон [14, с. 42]). Пелории льнянки были тщательно изучены ДеФризом в начале XX в. Растения льнянки с монструозными цветками фенотипически нестабильны, на отдельных ветвях у них встречаются частично или полностью нормальные цветки (нестабильность экс-
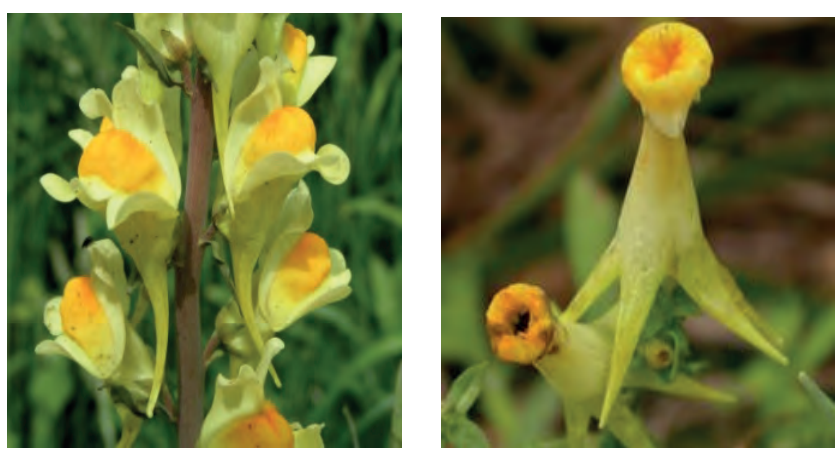

Льнянка обыкновенная (Linaria vulgaris) - травянистое многолетнее растение семейства Норичниковых (Scrophulariaceae). Справа - пелорическая форма прессии пелоризма цветков). Густафссон называет пелорические цветки «мутацией». Но частота генных мутаций на 4-5 порядков ниже, чем частота пелорий, изученных Де-Фризом. Таким образом, это не генная мутация, а другое наследственное изменение процесса морфогенеза. Сегодня растения с пелорическими цветками приводят в качестве наиболее наглядного примера эпигенетической изменчивости у растений [83].

Эпигенетически измененные признаки нередко наследуются в соответствии с правилами Менделя, что позволяет говорить об иерархии наследственных факторов, регистрируемых в рамках ЭГП. Другими словами, дискретный тип наследования можно наблюдать не только по признакам, которые контролируются генами, но и по признакам, которые детерминируются более крупными участками генома, или вообще без изменения ДНК (за счет ацетилирования гистонов - гистоновый код). Перечисленные особенности процесса наследования свидетельствуют о том, что такие разделы наук о наследственности, как менделизм, оперирующий понятием «наследственный фактор», и генетика, оперирующая понятием «ген», являются несколько различными дисциплинами, из которых первая была актуальна как в догеномную, так и в постгеномную эру, а вторая - только в постгеномную. Кодовое понятие менделизма - «наследственный фактор», не обязательно совпадает с кодовым понятием генетики - «ген». «Наследственные факторы ответственны за независимое наследование менделирующих признаков и связаны с определенными участками хромосом. В широком смысле понятие «наследственный фактор» применяется для обозначения совокупности многих влияний генетической и негенетической природы» [46, с. 432].

Мы знаем, что первый (низший) уровень организации наследственности - структура ДНК, открытая в 1953 г. Д. Уотсоном и Ф. Криком и немедленно превращенная в идеализированную икону, - управляет отнюдь не всеми признаками, свойствами и процессами в организме. Е.Д. Свердлов пишет: «Учебники рассматривают процесс репликации ДНК как систематическое движение ДНК-полимеразы вдоль одной линейной цепи ДНК, выстроенной подобно линии железной дороги. То же самое относится и к транскрипции, осуществляемой РНК-полимеразой. Создается впечатление, что геном - это открытая книга, готовая для чтения. Однако это не так. Книга закрыта, запечатана и запакована. Более того, все записано не просто на страницах этой книги. Функционирование ДНК зависит от многоступенчатой передачи информации разного рода. Оно не самым простым образом связано с ее последовательностью» [49, с. 498].

Следующий уровень структурной организации наследственного материала - хромосомы. «Не надо думать, что этот клубок может быть понят на основе идеальной двойной спирали» [49, с. 498]. С.А. Лавров и Е.В. Мавродиев [34] подчеркивают: «Веществом наследственности у эукариот является не ДНК как таковая, а хроматин - сложный комплекс ДНК и ряда белков, в числе которых гистоны и их аналоги - негистоновые хроматиновые белки, а также факультативные составляющие - транскрипционные факторы и компоненты систем транскрипции, репликации ДНК и репарации (субъединицы РНК и 
ДНК-полимераз, компоненты кинетохора, топоизомеразы, теломеразы, белки ядерной оболочки и многие другие; в хромосоме содержание белков в 2 раза больше, чем ДНК. - Авт.). Основной структурный элемент хроматина всех эукариот - нуклеосома. Это комплекс из восьми гистонов - по две молекулы четырех различных типов. Гистоны формируют глобулярную структуру (кор), на которую “намотана" ДНК, примерно 140 пар нуклеотидов (или 1,7 оборота) на нуклеосому».

На уровне хромосом работают системы дифференциальной активности генов, обеспечивающие тканевое разнообразие у каждой особи, экологически индуцируемые гены, продуцирующие белки теплового, холодового и других шоков [31], ацетилирование гистонов, регулирующее время цветения и другие эпигенетические процессы (в константной среде), обеспечивающие онтогенез [81].

Следующий уровень организации наследования и реализации свойств в онтогенезе - эпигенетический (известные эпигенетические феномены перечислены выше). Теорию эпигенов для фагов и вирусов развил Р.Н. Чураев [64], он же создал экспериментальную модель искусственного эпигена [63]. В 2005 г. вышли две капитальных коллективных монографии по эпигенетическому наследованию, развитию и изменчивости у растений $[67,86]$. Эпигенетические («надгенетические» или «реализационные») феномены не связаны с изменениями структуры генов и очень широко распространены в мире растений [70, 80].

А.Л. Маркель [40] подчеркивает: «Геноцентрическая парадигма наследственной передачи признаков сегодня рассматривается как недостаточная для объяснения всех механизмов наследования» и цитирует обзор E. Danchin et al. [76], в котором сказано: «Объединение дарвинизма и генетики в процессе так называемого синтеза привело к семантической путанице. В результате возникло мнение, что в чреде поколений наследуются только ДНК. Однако эволюция происходит путем отбора фенотипических особенностей (различий), которые, собственно, и наследуются в поколениях. Согласно этому фенотипические вариации должны быть разделены на наследуемые и ненаследуемые, а не на генетические и средовые, как это принято в классическом варианте эволюционной теории. В настоящее время представление о том, что биологическая информация передается в поколениях только через ДНК, выглядит несостоятельным. Это стало особенно очевидным, когда начали проводить полногеномные исследования ассоциаций (GWA genome-wide association studies). Эти исследования показали, например, что вариация таких признаков, как рост или заболеваемость широко распространенными болезнями, которые имеют высокие показатели наследования, не может быть объяснена изменчивостью, выявленной при полногеномном анализе. Отсутствие связи между вариациями ДНК и наследованием может быть обусловлено несколькими причинами, одна из которых - неправильная интерпретация самого наследования, из-за того что чисто генетическое наследование часто искажается негенетическим. Все большее признание находит понимание того, что в поколениях передаваться может также и негенетическая информация» [76, с. 114].

Уникальное открытие асимметрической изменчивости (или флуктуирующей асимметрии, ФА) было сделано Б.Л. Астауровым в конце 1920-х гг. при анализе наследования гомеозисной мутации "tetraptera" у Drosophila melanogaster [3]. Ученик и соратник Б.Л. Астаурова В.А. Струнников назвал открытый эпигенетический феномен «третья изменчивость»в дополнение к уже известным двум - генотипической и экологической (модификационной) изменчивостям [53]. А.Г. Васильев в своей замечательной книге [10] очень точно описал механизм ФА: «Проявление реализационной изменчивости (формирующей ФА. - Авт.), которая не связана ни с генотипом, ни с условиями внешней среды... обусловлено механикой развития. Данное явление прямо указывает на отсутствие однозначной связи между генами и дискретными вариациями признаков и хорошо согласуется с представлениями о существовании эпигенетической системы, которая порождает такого рода внутрииндивидуальную изменчивость» (C. 168).

И в настоящее время проблема отношений «гены признаки» далека от строгого решения. Вопрос: «Что есть ген?», возникший в 1909 г. (что такое «фактор», «зачаток» Г. Менделя?), актуален и поныне, и, по мнению В.С. Баранова и др. [4], «даже полное секвенирование ДНК геномов вовсе не снимает вопроса - "что есть ген?"».

И в довоенные годы, и в наши дни мы видим повторение дискуссий, возникших сразу же после 1900 г. (переоткрытия работ и законов Менделя). Так Н.И. Вавилов [7] писал: «Учение о корреляциях исчезает из селекционных руководств как устаревшее и опровергнутое. Генетическая, а за ней и селекционная мысль под влиянием менделизма устремляются к упрощенному пониманию организма как мозаики признаков, в которой можно заменять одни звенья другими. Отражение этих представлений можно найти и у советских генетиков (Н.К. Кольцов, А.С. Серебровский). Выведение сортов и пород представляется сравнительно простым делом. Устремление к схематизации, к упрощению явлений доходит до крайности» (С. 230). И далее: «Харланд стал объяснять поведение количественных признаков, например, длины волокна хлопчатника, действием десятков и даже сотен однозначных факторов, сводя генетические исследования к формальной эквилибристике» (С. 232). В итоге Н.И. Вавилов предлагает мудрый путь развития теории селекции: «Необходимо подходить к организму с учетом всей сложности комплекса признаков и свойств органов и их функций, их взаимоотношения со средой в развитии» (С. 233).

А.А. Жученко [26] подчеркивает: «Характерной особенностью адаптивных реакций в онтогенезе у высших эукариот является их интегрированность вследствие функциональной коадаптации генетического материала... что опровергает представление о геноме как о “мешке с бобами" и об адаптивных реакциях целостного организма как о “реестре” отдельных признаков» (С. 36).

Г. Кэксер [33] пришел к очень важному принципиальному результату: «Некоторые результаты развития могут определяться не генами, а кинетической структурой системы... Кинетическая система, основанная на иерархии катализаторов, обнаруживает тип поведения, обычно связываемый с генами, как функциональными единицами, являющимися основным предметом изучения генетики» 
(С. 63-64). Здесь Кэксер прямо говорит о существовании генов-фантомов, которые возникают в умах генетиков только потому, что многие из них твердо верят в гипотезу о высокой точности и воспроизводимости действия генов, хотя эта гипотеза не имеет строгих доказательств и, как будет показано ниже, не имеет никакого отношения к сложным временным процессам, таким как: онтогенез, яровизация, длина соломины злаков, формирование во времени компонентов продуктивности, урожая и т. п.

Наиболее универсальна, на наш взгляд, биосфероцентрическая парадигма жизни (БЦПЖ) В.И. Вернадского, сформулированная им в рамках учения о биосфере и ноосфере Планеты [39]. Ее отличиями от других концепций являются: а) биогеохимический взгляд на природу живого вещества на Земле; б) мультидисциплинарность - концепция охватывает несколько отраслей естествознания; в) учение о биосфере построено не «снизу вверх» (от простого к сложному), а «сверху вниз» (от сложного к простому); г) Вернадский связывает в единую систему атомарный уровень организации живого вещества и биосферные процессы, динамика которых определяется Космосом. Природу живого можно понять не через описание многообразия форм организации жизни на разных ее уровнях, а путем изучения эволюции биосферы как целостного объекта. Существенная часть БЦПЖ - роль пространственных (геометрических) свойств живого вещества. Вернадский особо выделяет диссимметрию органических молекул, которая рассматривается им не как отдельное свойство молекул, а как фундаментальная характеристика живого вещества, адекватная таким понятиям, как материя или энергия. БЦПЖ исключает противопоставление внутреннего и внешнего в развитии (например, генотипа и среды) и рассматривает реализацию жизненной программы как единый процесс.

\section{Основные парадигмы теории наследования и развития.}

Вернадский в рамках БЦПЖ характеризовал воспроизводство живого вещества как его наиболее существенное свойство. Процессы воспроизводства в ряду поколений называются наследственностью «подобное рождает подобное».

Из всего разнообразия подходов к изучению наследования и развития выделим две базовые парадигмы: ГЦП и ЭГП. Недавно их сложное противостояние и взаимодействие на протяжении последних десятилетий мы постарались строго описать [38]. Первая из них - преформистская, считающая гены, образно говоря, «диктаторами» (генералами), отдающими через метаболические пути «команды» признакам, которые согласно «приказу» проявляют определенное качество (качественные признаки), или определенную величину или число (количественные признаки). Строгое и бескомпромиссное следование одной из парадигм вызывает у некоторых исследователей мифологизацию сознания. Например, некоторые бескомпромиссные сторонники ГЦП считают, что единицей эволюции является ген (последовательность ДНК) [15], а не популяция, как это следует из теории микроэволюции. В высоко-импактных научных журналах публикуются работы, пропагандирующие «молекулярную» селекцию растений [84, 92], хотя отбор по молекулярным характеристикам на повы- шение продуктивности и урожая на уровнях растений или делянок (именно на этих уровнях возникает эмерджентный феномен «взаимодействие генотипсреда»), как правило, бессмыслен. Многие авторы, к сожалению, не учитывают то обстоятельство, что сложные признаки хозяйственной продуктивности и урожая растений не наследуются подобно простым менделевским признакам, а являются сложными процессами, развивающимися во времени, в тесном взаимодействии с меняющимися в течение суток, недель, месяцев лимитирующими факторами внешней среды. К тому же эти процессы реализуются на фоне дифференциальной активности генов, проявляющейся на разных фазах развития растений. Н.И. Вавилов еще в 1935 г. писал: «Мы не будем удивлены, если основательное изучение наследственности количественных признаков приведет к коренной ревизии упрощенных менделистических представлений» [8, с. 275]. К сожалению, сегодня «упрощенные менделистические представления» сохраняются в основе традиционной (менделевской), биометрической и молекулярной ветвей генетики.

Еще в начале 1970-х гг. академик В.А. Энгельгардт призывал развивать интегратизм - путь от простого к сложному в познании явлений жизни [66]. Он осознал, что классический редукционизм, господствующий в биологии и сегодня (ГЦП - это итог редукционизма в генетике), не способен создать адекватные методы управления сложными биосистемами - организмами, популяциями, фитоценозами, биогеоценозами, ландшафтами, ноосферой, биосферой.

Академик П.К. Анохин [1] уже давно сформулировал важнейшее свойство систем: «Целое, или система, обретает свои собственные принципы организации, не переводимые на принципы и свойства тех отдельных компонентов и процессов, из которых она формируется».

Известный молекулярный генетик Гюнтер Стент еще в 1974 г. предупреждал: «Поиски “молекулярного” объяснения сознания являются напрасной тратой времени, поскольку физиологические процессы, ответственные за это ощущение, задолго до того, как будет достигнут молекулярный уровень, распадутся до ординарных рабочих реакций, не более удивительных, чем процессы, происходящие, например, в печени» [52, с. 524]. Тем самым Стент дал прекрасную иллюстрацию известному тезису А. Сент-Дьерди: «Одним из основных принципов жизни является “организация": мы понимаем под этим, что при объединении двух вещей рождается нечто новое, качества которого не аддитивны и не могут быть выражены через качества составляющих его компонент» [51, с. 41]. Работы Сент-Дьерди подчеркнули важность изучения неаддитивных эффектов взаимодействия компонент сложной системы, так называемых эмерджентных (заново возникающих) свойств. Именно существование таких свойств обусловило необходимость разделить биологию на несколько уровней организации. На каждом более высоком уровне возникают новые эмерджентные свойства, которых не было вообще на более низком уровне организации. Например, популяционная генетика изучает эмерджентное свойство - частоту конкретного аллеля в данной популяции. Этого свойства нет вообще на уровне классической генетики при проведении парных скрещиваний. Одум [41, с. 17] пришел к выводу: «Принцип несво- 
димости свойств целого к сумме свойств его частей должен служить первой рабочей заповедью экологов» (цит. по [47]) (а также, добавим мы, экологических генетиков и эпигенетиков). Свердлов в работе «Биологический редукционизм уходит? Что дальше?» [50] отмечает, что путь интегрирования - это путь к высшему пониманию жизни. В своей замечательной работе Розенберг [47, с. 831], критикуя редукционизм, цитирует американских физиков Н. Голденфельда и Л. Каданоффа - «для описания бульдозера излишне использовать кварки», то есть надо всегда следовать принципу «бритвы Оккама» - не создавать без необходимости новые сущности.

\section{Селекция растений}

Селекция растений, или биотехнология in vivo, набор технологий и методов создания новых сортов и гибридов, обладающих нужными экономически значимыми свойствами. Возраст селекции исчисляется несколькими тысячелетиями, а возраст генетики лишь недавно перевалил за 100 лет. Этот возрастной разрыв позволяет подобрать из истории селекции достаточное число примеров, из которых следует, что выдающиеся успехи селекции были достигнуты задолго до появления менделизма и отнюдь не в рамках ГЦП.

Так в 1852 г. Луи Вильморен предложил проводить оценку сахарной свеклы по комплексу хозяйственноценных свойств (с последующими гибридизацией и отбором) не по средним величинам признаков популяций, а у индивидуальных потомств. Это позволило ему создать совершенно новый тип растений, ранее не известный в природе. Если содержание сахара в корнях у исходных популяций варьировало в пределах 6-8\%, то у вновь отобранных индивидуальных потомств содержание сахара достигло 14-16\% [42]. Этот уровень фактически сохраняется и поныне. В своих представлениях Вильморен ориентировался на ОЦП наследования. Следует подчеркнуть, что это выдающееся достижение селекции растений произошло за полтора десятилетия до начала опытов Г. Менделя и за полвека до рождения формальной генетики.

\section{Теория эколого-генетической организации количественных признаков (ТЭГОКП) - теория, базирующаяся на ЭГП}

Нами предпринята попытка рассмотреть проблему взаимоотношений между комплексом наук о наследственности и селекцией в рамках ТЭГОКП. Проблему взаимоотношений генетики и селекции подчеркнул Н.И. Вавилов еще в 1935 г.: «Между искусством селекции и генетикой лежит очень глубокая пропасть, и нужно сделать многое, чтобы перекинуть через нее мост» [8].

Показано, что современные теории наследования и развития (классическая, биометрическая и молекулярная ветви генетики), претендующие быть теоретическими основами селекции, до недавнего времени мало способствовали решениям задач, без которых невозможно построить количественную теорию селекции растений для эколого-генетического улучшения сложных экономически важных количественных свойств растений, в первую очередь продуктивности и урожая. Оказалось, что к 70-80-м гг. прошлого века существовала не одна, а 14 «пропастей» между тремя ветвями генетики и практической селекцией [24, 77,]. Эти «пропасти» удалось отчасти «засыпать» с помощью развития ТЭГОКП и 24 следствий из нее, развитых в период 1984-2014 гг. Главный блок экспериментальных данных получили при выполнении Межведомственной кооперированной программы ДИАС (диаллельные скрещивания для изучения генетики признаков продуктивности яровых пшениц в Западной Сибири). Программу инициировал акад. Д.К. Беляев (директор Института цитологии и генетики СО АН - куратор программы) при активной поддержке со стороны Председателя СО АН акад. М.А. Лаврентьева и, позднее, сменившего его на этом посту акад. Г.И. Марчука (впоследствии Председателя ГКНТ СССР и затем Президента АН СССР). Программа выполнялась с 1973 по 1983 г. силами 9 селекционных центров ВАСХНИЛ и двух институтов СО АН, числом специалистов более 100 человек. Были организованы скрещивания (каждого сорта с каждым) 15 сортов из нескольких стран мира. Родительские сорта, гибриды первого и второго поколений выращивали по стандартным схемам в 9 географических точках в течение двух лет в случайных блоках, в 4-кратной повторности. В рядке каждого блока - 40 учетных растений. На каждом растении замеряли 19 количественных признаков. Данные (5 млн замеров признаков продуктивности) обрабатывали по специально созданным программам диаллельного анализа на ЭВМ Вычислительного центра СО АН (куратор вычислений акад. Г.И. Марчук). В 1984 г. вышла коллективная монография [17].

В 1984 г. группой исследователей, участвующих в анализе данных программы ДИАС, был обнаружен новый эпигенетический феномен (НЭФ) - смена спектров и числа генов, детерминирующих один и тот же количественный признак, при смене лимитирующего фактора внешней среды, и была опубликована новая Модель эколого-генетического контроля количественных признаков растений (МЭГККП) [18].

В период 1984-2014 гг. на основе тщательных исследований причин и механизмов НЭФ и совершенствования МЭГККП были развиты теоретически и проверены экспериментально 24 новых селекционно важных следствия МЭГККП [23] и 9 мощных ноу-хау, позволяющих существенно повысить скорость и эффективность селекционного процесса с растениями [24]. В результате была создана Теория эколого-генетической организации количественных признаков (ТЭГОКП), наиболее компактно изложенная в [23].

Главное положение теории: при смене лимитирующего рост и развитие растения фактора внешней среды меняются спектр и число генов, детерминирующих один и тот же количественный признак (КП). Показано, что признаки «интенсивность транспирации» и «интенсивность фотосинтеза» в течение суток детерминируются поочередно двумя и тремя разными спектрами генов соответственно [71]. Механизм этого явления сейчас стал вполне очевиден. Известно [69], что общее число генов, экспрессируемых в клетках человека, - около 24000, из которых 11000 экспрессируются в клетках любого типа. Если этот принцип справедлив для растений, то очень легко объяснить результаты следующих опытов. Если два сорта пшеницы: один с геном Lr (устойчивость к бурой ржавчине), другой - без этого гена - высеять рядом и заразить спорами бурой ржавчины, то у пер- 
вого сорта только продукт одного гена $\mathrm{Lr}$ - фитоантисипин - будет «подпирать» признаки продуктивности, а у второго сорта эти признаки будут развиты очень слабо (больные растения). При скрещивании этих сортов на фоне бурой ржавчины в поколении $\mathrm{F}_{2}$ мы получим расщепление по признакам продуктивности $3: 1$ - результат влияния продукта только одного гена, хотя параллельно с ним экспрессируются тысячи других генов. На фоне без ржавчины моногенная детерминация признаков продуктивности исчезает, а их наследование традиционно описывается с помощью гипотезы полигении. Таким образом лим-фактор среды «заставляет» влиять на признак продукты тех генов, которые обеспечивают наибольшую защиту данного генотипа от негативного воздействия данного лим-фактора.

В 2008 г. ТЭГОКП получила подтверждение на уровне традиционного картирования локусов количественных признаков (QTL) $[61,72]$ в совместном исследовании с генетиками Германии и, позднее, - в широких экспериментах в разных географических точках России [54, 62].

Недавно Брюс Липтон опубликовал свою очень сходную с ТЭГОКП теорию [35], созданную им при изучении реакций клеток человека на средовые воздействия. Но его первые публикации вышли из Стэнфордского университета только в 1991 г., тогда как ТЭГОКП появилась в ДАН СССР в 1984 г. ${ }^{1}$

Элементы ТЭГОКП включены в Международную энциклопедию «Basic Life Science», New York - Boston - London, Vol. 8 - Genetic Diversity in Plants PP. 233-240, а краткое изложение теории опубликовано в Толковом словаре по общей и молекулярной биологии, общей и прикладной генетике, ДНК-технологии и биоинформатике [55, т. 2, с. 308]. На базе ТЭГОКП созданы элементы инновационных технологий эколого-генетического повышения продуктивности и урожая, некоторые из них сегодня успешно работают в более чем 30 российских и зарубежных генетических и селекционных центрах [22].

ТЭГОКП прояснила причины того, почему «превращение дикорастущих видов растений в сельскохозяйственные произошло без всякого применения достижений современной генетики и каких-либо представлений менделевской генетики. Современные селекционеры растений с успехом применяют в основном эту же стратегию» [45, с. 270]. Стало понятным, почему «никакой существенной корреляции между конечной урожайностью и эффективностью какого-либо определенного биохимического пути не обнаружено» [45, с. 275].

\section{ЭГП и фундаментальные положения традиционных наук о наследственности - менделевской, биометрической и молекулярной ветвей генетики}

Эти три ветви современной генетики базируются на ГЦП, а ТЭГОКП - на ЭПГ. Различия в концептуальных подходах ведут к различиям в понимании и интерпретации биологических процессов, что отнюдь не приводит к ясности при работе с селекционным материалом. Сегодня на базе ТЭГОКП обнаружены и исследованы реальные механизмы многих

\footnotetext{
${ }^{1}$ Принимая положения Б. Липтона о доминантной роли лимитирующих факторов среды в развитии клеток, мы не можем принять гипотезу о том, «как влияет мышление на гены, клетки и ДНК».
}

феноменов, которые традиционная генетика называет генетическими, а ТЭГОКП считает их эпигенетическими (эколого-генетическими).

С позиций ГЦП и ЭГП механизмы одного и того же феномена выглядят совершенно по-разному.

Рассмотрим несколько примеров вероятного появления генов-фантомов в рамках ГЦП.

1. В традиционной генетике давно существует каталог менделевских генов яровизации пшениц. Однако недавние исследования $[71,90]$ показали, что довольно длительный и сложный процесс яровизации (не признак, а именно процесс) имеет эпигенетическую природу. С этих позиций необходимо более тщательно изучить существующий каталог генов яровизации, исследовав поведение каждого «гена» в градиенте низких температур с позиций ЭГП.

2. В традиционной генетике уже давно существует каталог генов короткостебельности пшениц, то есть постулируется, что укорочение стебля детерминируется одним (или двумя-тремя) «большими» генами Г. Менделя. Однако программа ДИАС [17] показала, что генетика длины каждого междоузлия отлична от таковой всех других междоузлий и меняется для каждого междоузлия специфически при смене динамик лим-факторов среды в разных географических точках. Кроме того, сорта, не имеющие гена короткостебельности, но созданные в мезофитных условиях (например, в Швеции), на фоне засухи в Усть-Каменогорске имеют длину стебля меньшую, чем сорта, имеющие такой ген, но обладающие большей засухоустойчивостью. Налицо феномен взаимодействия «генотип-среда» (ВГС), то есть смена рангов по высоте, а ВГС - это эпигенетический феномен.

Жесткий каталог генов короткостебельности и факты ВГС по длине соломины находятся в противоречии, которое требует дополнительного изучения поведения образцов каталога генов короткостебельности и причин смены рангов по длине соломины в разных средах в рамках ЭГП.

3. В программе ДИАС мы изучали с позиций ГЦП генетику гомеостаза продуктивности (пластичности) сортов [17], построив матрицу Хеймана из коэффициентов регрессии 15 сортов и их гибридов $\mathrm{F}_{1}$ по экологическому градиенту - от географической точки с минимальной средней продуктивностью к точке с максимальной. ЭВМ выдала нам вполне значимые все генетические параметры Хеймана, включая параметр «число генов, детерминирующих гомеостаз продуктивности». Оказалось, что только один ген определяет различие по пластичности сортов. Этот ген - есть достоверный ген-фантом, поскольку природа пластичности оказалась совершенно иной. Анализ тех же материалов методами ТЭГОКП показал реальную природу гомеостаза продуктивности. Его механизм таков: если один сорт обладает хорошими генетико-физиологическими системами засухоустойчивости и холодостойкости, а другой - хорошей засухоустойчивостью, но плохой холодостойкостью, то в двух средах - «засуха» и «холод» - первый проявит гомеостаз продуктивности, второй резко снизит продуктивность на фоне холода (не пластичный сорт). Природа реальной пластичности сорта - это смена спектров генов под компонентами продуктивности при смене лим-факторов внешней среды, то есть в ее основе лежит эпигенетический (эколого-генетический) механизм. 
4. С позиций ГЦП доминирование количественных признаков имеет тот же механизм, что и качественных: для доминирования нужны доминантные гены (в менделевской генетике) и, соответственно, доминантные полигены в биометрической генетике. Анализ природы доминирования и ее смен с позиций ТЭГОКП [78] показал, что смена доминирования КП в разных средах - есть смена спектров продуктов генов при смене лим-фактора среды, то есть доминирование КП и смена доминирования КП имеют эпигенетическую природу.

5. С позиций ГЦП феномен гетерозиса имеет генетическую природу (гипотезы гетерозиса: накопление доминантных аллелей, сверхдоминирование, компенсационный комплекс генов и т. п.). Эти гипотезы существуют как в менделевской генетике, так и в биометрической (анализ «сверхдоминирования» по Б. Хейману предполагает тот же механизм взаимодействия двух аллелей в локусе, что и в менделевской генетике).

Нам удалось на основе ТЭГОКП получить в фитотроне, давая засуху в фазу кущения и холод в фазу налива (типичные лим-факторы в Западной Сибири), эффект гетерозиса по продуктивности у яровой пшеницы около $100 \%$ от лучшего родителя и доказать, что природа экологически зависимого гетерозиса это не генетические механизмы, постулированные ГЦП, а эпигенетические (или, что то же самое, - эколого-генетические) [44]. К такому же выводу пришли другие коллективы [37].

\section{Рассмотрим природу некоторых селекционно- важных феноменов с позиций ГЦП и ЭГП}

1. Природа феномена «взаимодействие генотипсреда» (ВГC)

В рамках ГЦП современные ветви наук о наследственности (менделевская, биометрическая, молекулярная) до сих пор не имеют ни одной гипотезы о механизме феномена ВГС (смене рангов генотипов по продуктивности в разных средах), хотя сам феномен ВГС есть главный «рычаг» повышения продуктивности и урожая в селекции растений [21]. С позиций ТЭГОКП, ВГС - это смена спектра продуктов генов при смене лим-фактора внешней среды [23]. Эффекты ВГС можно прогнозировать путем сравнения типичных динамик лим-факторов в зоне создания сорта и в зоне, куда сорт предполагается интродуцировать [23].

2. Природа трансгрессий

В рамках ГЦП учебники генетики приводят такой механизм трансгрессий: ААвв $\times$ аaВB $=$ AАBB. Эта гипотеза ничего не дает селекционеру, так как он никак не может в коллекционном питомнике найти генотипы ААвв и аaВB, поэтому вынужден «отлавливать» трансгрессии методом «проб и ошибок», производя тысячи скрещиваний. В рамках ЭГП (ТЭГОКП) трансгрессии - это поочередная смена генетико-физиологических систем у гибридов под компонентами продуктивности на разных лим-факторах [23]. Трансгрессии для конкретной зоны селекции можно прогнозировать, зная типичные динамики лим-факторов в географических точках происхождения сортов-родителей [23].

3. Природа генотипических коррелящий

В учебниках генетики утверждается, что меха- низм генотипических корреляций - это плейотропия или сцепление генов. Но тогда генотипические корреляции должны быть стабильны в разных средах. Фактически величины и знаки генотипических корреляций обнаруживают «пляску святого Витта» от среды к среде. Гипотезы плейотропии и сцепления (созданные в рамках ГЦП) не проходят. В рамках ЭГП сдвиги знаков и величин генотипических корреляций есть результат смены спектров продуктов генов при смене лим-факторов среды. Из ТЭГОКП вышли методы строгого прогноза сдвигов знаков и величин коэффициентов генотипической корреляции в разных средах [23].

\section{4. ГЦП и морфогенез}

По определению, морфогенез - это процесс возникновения и формирования многоклеточных структур в ходе роста и развития растений. Представления о генезисе морфопризнаков в рамках ГЦП построены в рамках логических конструкций, предполагающих почти прямую зависимость морфогенеза от активности отдельных генов или некоторого их числа. Обсуждаются такие искусственные симулякры ${ }^{2}$, как «один ген - один признак», «два гена - один признак», «три гена - один признак» и т. п., включая и влияние на признак большого числа генов (полигения). В противоположность этому в рамках ЭГП морфогенез рассматривается не как детерминированный генами признак, а как идущие во времени процессы самосборки, реализуемые путем самоусложнения молекулярных и надмолекулярных компонентов клеток в постоянном взаимодействии с меняющимися в течение суток, недель, месяцев лим-факторами среды.

Реализуемую во временном диапазоне динамику развития, по-видимому, нельзя описывать в рамках ГЦП, которая заточена, как известно, на процессы передачи генов от одного поколения к другому и не рассматривает процессы развития и формирования конечных сложных признаков. Это методологическое ограничение менделизма и современной ГЦП обсуждается уже давно. «Проблема наследственности оказалась искусственно разбитой на проблему наследственной передачи и проблему наследственного осуществления. Такое разделение проблемы наследственности на две проблемы, теряющие между собой связь, несомненно, является глубоко неправильным. Генетика, решающая только проблему передачи, а не проблему осуществления, перестает видеть организм в его развитии - в его динамике, а берет его в статике» (Гришко и Делоне [13], с. 4). Между тем, динамика развития и самоусложнения морф во времени не противоречат принципам новообразования признаков, декларируемых ЭГП, как непрерывно идущего эпигенетического процесса.

В рамках ГЦП морфогенез - есть процесс, управляемый дифференциальной активностью генов по фазам онтогенеза [56]. Однако Л.В. Белоусов [5] пришел к другому выводу: «Геном и морфогенез - сущности совершенно разного порядка. При всех изменениях взглядов на гены со времен Менделя они всегда рассматриваются как статистические дискретные факторы, тогда как морфогенез - это разворачивающийся в пространстве-времени континуальный

\footnotetext{
Симулякр - копия, не имеющая оригинала в реальности, репрезентация чего-то, что на самом деле не существует. Например, древняя фотография группы людей — симулякр той реальности, что на ней оотография
} 
(нерасчлененный по ходу своему на отдельные признаки) процесс. Даже если принять, что каждый шаг морфогенеза связан с активацией или репрессией определенных генов (на самом деле это не так), то пространственно-временное расписание активации/ репрессии генов должно определяться не ими самими, а вне-(эпи)-генетическими факторами, прямо или косвенно связанными с морфогенезом» (С. 29). С.В. Савельев [48] описал 13 новых подстадий нормального развития головного мозга человека и более 200 случаев нарушений в его работе у эмбрионов. Оказалось, что самые ранние стадии формирования головного мозга зависят не столько от работы генов, сколько от взаимодействия клеток друг с другом.

Общеизвестны морфогенезы у кристаллов, образование ледяных узоров (схожих с листьями растений) на замерзшем оконном стекле, самые разные типы морфогенезов снежинок, развитие дендритов (маленьких деревьев, например, из меди), вырастающих при электролизе металлов на бортах электрохимической ванны и т. п. Эти примеры показывают, что морфогенез в широком смысле слова может реализовываться за счет процессов самоорганизации форм из набора совершенно одинаковых молекул и может совсем не контролироваться генами (в приведенных примерах о генах не может быть и речи) [38, с. 18].

5. Биометрическая генетика и ЭГП (ТЭГОКП)

Все методы биометрической генетики (К. Мазер, Дж. Джинкс, Б. Хейман и др.) - это положения традиционной менделевской генетики, перенесенные на ситуации, когда четкая гистограмма расщеплений в генерации $\mathrm{F}_{2}$ исчезает и возникает нормальное (для ростовых процессов - логнормальное) распределение генотипических значений КП отдельных индивидуумов. Фундаментом биометрической генетики служит гипотеза о полигенах, выдвинутая только лишь на основании фактов отсутствия четких менделевских расщеплений в $\mathrm{F}_{2}$ [43].

ТЭГОКП показала, что превращение гистограммы Менделя в нормальное распределение имеет совершенно иной механизм, чем тот, который постулирует гипотеза полигении [23]. «В каждый короткий момент времени любой количественный признак является моногенным (его генетическая изменчивость в популяции детерминируется одним “узким местом" - одним геном - в определенном метаболическом пути). Однако при смене лим-фактора внешней среды ранее детерминирующий данный признак ген сменяется другим геном, детерминирующим тот же признак, но лежащим в другом метаболическом пути, и очень часто в другой хромосоме. Это приводит к “смазыванию” классической гистограммы расщепления по Менделю, возникает кривая нормального (логнормального) распределения, в которой невозможно выделить классы расщеплений» [30, c. 22]. При этом не существует никакого «набора генов» («полигенов»), которые бы одномоментно (одновременно) детерминировали бы признак, точно так же, как нет и набора одномоментно действующих на признак QTLoв.

Кривая нормального распределения возникает не потому, что много генов (полигены) одновременно вносят каждый свой вклад в величину количественного признака, а потому, что в каждый последующий небольшой промежуток времени продукт другого гена начинает детерминировать тот же признак, при- дя на смену продукту первого гена, при смене прежнего лим-фактора среды на новый [20, с. 113-114].

Интересно, что аналогичные явления обнаружены при исследовании экспрессии гена Dscam (Down syndrome cell adhesion molecule) у дрозофилы [74]. Этот ген содержит 95 альтернативных экзонов и контролирует за счет альтернативного сплайсинга 38016 различных мРНК. Альтернативный сплайсинг регулируется в ходе развития, кроме того разные ткани взрослых особей содержат различные наборы изоформ мРНК. В следующей публикации [73] показано, что каждый ген насекомых (Dscam) может потенциально генерировать десятки тысяч изоформ мРНК. Из этого следует принципиальный вывод: «Экспрессия огромного числа изоформ мРНК более важна для развития и функционирования нервной системы насекомых, чем действительный сиквенс каждой изоформы мРНК». С позиций ТЭГОКП это означает, что каждая фаза онтогенеза и каждая ткань организма при развитии в константной среде «выбирают» для себя оптимальный набор изоформ, а при смене лимфакторов внешней среды каждый лим-фактор «вызывает огонь на себя» определенным «залпом» определенного набора изоформ мРНК.

Известно, что после 20 лет коллективной работы «того результата, которого ждала мировая научная общественность, международный проект “Геном человека" пока не принес» [25]. В 2010 г. начала работу более сложная программа «Протеом человека», «для которой потребуется гораздо больше времени». Россия изучает протеомику 18-й хромосомы, несущей 276 генов. По мнению акад. А.И. Арчакова [25] необходимо найти и оценить белки основного протеома (немодифицированные белки, из которых 269 из 276 уже изучены), затем - белки, модифицированные на геномном уровне (содержащие одноаминокислотные замены), затем - белки, модифицированные на транскриптонном уровне (экспрессированные альтернативным сплайсингом (что самое сложное. - Aвm.)), наконец белки, модифицированные на посттрансляционном уровне (химически модифицированные белки). В итоге будет получен полный протеом 18-й хромосомы человека. С позиций ТЭГОКП этих знаний вряд ли будет достаточно для прогнозирования поведения результирующих сложных свойств целостного организма ввиду перманентной смены (даже в течение суток) наборов продуктов разных генов, детерминирующих признак, соответственно смене лим-факторов внешней среды. Взаимоотношениям геномно-протеомных подходов и следствий ТЭГОКП будет посвящена наша следующая статья.

Рассмотрим с позиций физиологии растений реальный механизм возникновения генотипических различий, например, по массе 1000 зерен у пшеницы. Допустим, у нас есть два сорта, у первого - толстая прочная кутикула, у второго - тонкая и рваная (генетический дефект). В жарком климате в полдень устьица первого и второго сортов будут закрыты, транспирация у первого сорта почти прекратится, листья не будут охлаждаться транспирацией, в результате перегрева растений масса 1000 зерен (М3) будет низкой. У второго сорта кутикулярная транспирация в полдень (благодаря рваной кутикуле) будет охлаждать листья, МЗ будет выше, чем у первого сорта, то есть генетический дефект кутикулы повышает МЗ в условиях жаркого климата. В условиях прохладного, 
но сухого климата первый сорт будет лучше сохранять влагу (меньше транспирировать) по сравнению со вторым и сформирует признак М3, превышающий МЗ второго сорта.

Другой пример. Если один сорт имеет низкую засухоустойчивость в фазе кущения, когда формируется признак «число зерен в колосе», то при засухе в эту фазу он даст мало зерен, но если у него нормальные гены аттракции, активно работающие в фазу налива, то это приведет к сильному повышению МЗ. То есть слабая засухоустойчивость в фазу кущения (генетический дефект) резко увеличивает «массу 1000 зерен». Современные формальные методы поиска QTLoв, созданные на основе ГЦП, в первом примере дадут вполне предсказуемый, но достаточно нелепый результат: в одной среде (на жаре) они локализуют ген дефекта кутикулы на одной хромосоме (называя его «геном большой массы 1000 зерен»), в другой среде (на засухе) локализуют нормальный ген толстой и прочной кутикулы в другой хромосоме (опять называя его «геном большой массы 1000 зерен»). Если три дня в фазу налива была жара после дождя, а следующие три дня - легкая засуха без жары, то за одну неделю главный QTL M3 с большой вероятностью сменит свое положение на хромосомах. Во втором примере - слабая засухоустойчивость в фазе кущения (генетический дефект) - на фоне засухи в эту фазу - увеличит признак МЗ, а при отсутствии засухи - уменьшит его.

Такие физиологические механизмы развития целостного растения не вполне осознаются генетиками, которые занимаются поисками полигенов и QTLoв, игнорируя необходимое параллельное изучение динамики лимитирующих факторов среды по фазам развития и смену спектров продуктов генов «под признаком» при смене такого фактора внешней среды.

\section{ЛИТЕРАТУРА}

\section{Список русскоязычной литературы}

1. Анохин П.К. Узловые вопросы теории функциональных систем. М.: Наука; 1980.

2. Аршинов В.И., Буданов В.Г. Роль синергетики в формулировании новой картины мира. В кн.: Вызов познанию. Стратегии развития науки в современном мире. М.: Наука; 2004. $386 \mathrm{c}$.

3. Астауров Б.Л. Наследственность и развитие. М.: Наука; 1974. 359 с.

4. Баранов В.С., Баранова Е.В., Иващенко Т.Э., Асеев M.B. Геном человека и гены предрасположенности. (Введение в предиктивную медицину). СПб.: Интермедика; 2000.

5. Белоусов Л.В. Морфогенез, морфомеханика и геном. Вестник ВОГиС. 2009;13(1):29-35.

6. Богданова Е.Д., Махмудова К.Х. Эпигенетика мягкой пшеницы. Алматы; 2012. 106 с.

7. Вавилов Н.И. Критический обзор современного состояния генетической теории селекции растений и животных. В кн.: Вавилов Н.И. Закон гомологических рядов в наследственной изменчивости. Л.: Наука; 1987. с. 224-46.

8. Вавилов Н.И. Избранные труды. Т. 5. М-Л.; 1965. c. 275.

9. Ванюшин Б.Ф. Материализация эпигенетики или небольшие изменения с большими последствиями. Химия и жизнь. 2004;(2):32-7.

10. Васильев А.Г. Эпигенетические основы фенетики: на пути к эволюционной мерономии. Екатеринбург; 2005. 640 с.

11. Галиикий В.А. Гипотеза о механизме инициации малыми РНК метилирования ДНК de novo и аллельного исключения. Цитология. 2008;50(4):277-86.

12. Голубовский М.Д. Век генетики: эволюция идей и понятий. СПб: Borey Art; 2000. 262 с.

13. Гришко Н.Н., Делоне Л.Н. Курс генетики. М.: Сельхозгиз; 1938. 354 с.
14. Густафссон А. Вавилов и параллельная изменчивость. В кн.: Генетика и благосостояние человечества. М.: Наука; 1981. с. 40-53.

15. Докинз P. Эгоистичный ген. М.: Мир; 1993.

16. Драгавиев В.А., Сахаров В.И. К методике статистического анализа длительных модификаций в растительных популяциях. Журнал общей биологии. 1972;(6):733-9.

17. Драгавиев В.А., Цильке Р.А., Рейтер Б.Г. и $\partial p$. Генетика признаков продуктивности яровых пшениц в Западной Сибири. Новосибирск: Наука СО АН; 1984. 230 с.

18. Драгавиев В.А., Литун П.П., Шкель Н.М., Нечипоренко Н.Н. Модель эколого-генетического контроля количественных признаков растений. Доклады АН СССР. 1984;274(3):720-3.

19. Драгавцев B.A. Новый метод генетического анализа полигенных количественных признаков растений. В кн. Идентифицированный генофонд растений и селекция. СПб: ВИР; 2005. c. 20-35.

20. Драгавиев В.А. Проблемы преодоления разрывов между генами и признаками в современной селекции. Известия ТСХА. 2009;(2):110-22.

21. Драгавцев В.А., Макарова Г.А., Кочетов А.А., Кочерина Н.В., Мирская Г.В., Синявина Н.Г. Некоторые задачи агрофизического обеспечения селекционных технологий для эколого-генетического повышения продуктивности и урожая растений. Агрофизика. 2011;(1):14-22.

22. Драгавиев В.А. Эколого-генетическая организация количественных признаков растений и теория селекционных индексов. В кн. Экологическая генетика культурных растений. Краснодар: ВНИИ риса; 2012. с. 31-50.

23. Драгавцев B.A. Уроки эволюции генетики растений. Биосфера. 2012;4(3):251-62. 
24. Драгавиев В.А. Как помочь накормить человечество. Биосфера. 2013;5(3):279-90.

25. Дризе Ю. От генома к протеому. Поиск. 2014;(52):6.

26. Жученко А.А. Генетическая природа адаптивного потенциала возделываемых растений. В кн.: Идентифицированный генофонд растений и селекция. СПб: ВИР; 2005. с. 36-101.

27. Инге-Вечтомов С.Г. Прионы дрожжей и центральная догма молекулярной биологии. Вестник РАН. 2000;70(4):299-306.

28. Кононков П.Ф. Очерк о развитии биологии и сельскохозяйственных наук в советский период. М.: РУДН; 2007. 82 с.

29. Корочкин Л.И. Биология индивидуального развития. М.: Изд-во МГУ; 2002. 264 с.

30. Кочерина Н.В., Драгавцев В.А. Введение в теорию эколого-генетической организации полигенных признаков растений и теорию селекционных индексов. СПб: АФИ-Дон Боско; $2008.87 \mathrm{c}$.

31. Кузнецов В.В., Дмитриева Г.А. Физиология растений. М.: Абрис; 2011. 784 с.

32. Кун T. Структура научных революций. М.: Иностранная литература; 1975. 258 с.

33. Кэксер Г. Кинетические модели развития и наследственности. В кн.: Моделирование в биологии. М.: Иностранная литература; 1963. c. $42-64$.

34. Лавров С.А., Мавродиев Е.В. Эпигенетическое наследование признаков и его возможная роль в микроэволюции растений. Журнал общей биологии. 2003;64(5):403-20.

35. Липтон Б. Умные клетки: биология убеждений. Изд-во София; 2011. 224 с. (In Russ. Translated from: Lipton B. The Wisdom of Your Cells.)

36. Лобашев М.Е. Генетика. 2-е изд. Л.: ЛГУ; 1967.

37. Малечкий С.И., Мелентьева С.А., Татур И.С., Юданова С.С., Малеикая Е.И. Сохранение гибридной мощности в апозиготическом потомстве сахарной свеклы. Вестник НАН Беларуси. Сер. агрон. наук. 2013;(1):65-72.

38. Малеикий С.И., Роик Н.В., Драгавиев В.А. Третья изменчивость, типы наследственности и воспроизводство семян у растений. Сельскохозяйственная биология. 2013;(5):3-29.

39. Малеикий С.И. Геометрический код жизни Владимира Вернадского. Вестник украинского общества генетиков и селекционеров. 2013;11(2):321-48

40. Маркель А.Л. Физиологическая генетика. Вавиловский журнал генетики и селекции. 2014;18(1):112-24.

41. Одум Ю. Экология. Том 1. М.: Мир; 1986.

42. Паншин БА. Селекция сахарной свеклы. В кн.: Теоретические основы селекции растений. Том 3. М-Л.: Госсельхозиздат; 1937. с. 439-82.

43. Ратнер В.A. Генетика, молекулярная кибернетика. Личности и проблемы. Новосибирск: Наука; 2002. 172 с.

44. Рахман М.М., Драгавиев В.А. Новые подходы к прогнозированию гетерозиса у растений. Сельскохозяйственная биология. 1990;(1):3-12.
45. Рекомбинантные молекулы: значение для науки и практики. М.: Мир; 1980.

46. Ригер Р., Михаэлис A. Генетический и цитогенетический словарь. М.: Колос; 1967. 607 с.

47. Розенберг Г.С. Холизм + редукционизм: две дороги к храму. Вестник РАН. 2014;84(9):830-3.

48. Савельев C.В. Изменчивость и гениальность. М.; 2012.

49. Свердлов Е.Д. ДНК в клетке: от молекулярной иконы к проблеме «что есть жизнь». Вестник РАН. 2003;73(6):497-505.

50. Свердлов Е.Д. Биологический редукционизм уходит? Что дальше? Вестник РАН. 2006;(8):707.

51. Сент-Дьерди А. Введение в субмолекулярную биологию. М.; 1966.

52. Стент Г. Молекулярная генетика. М.: Иностранная литература; 1974. 320 с.

53. Струнников B.A. Третья изменчивость. Природа. 1989;(2):17-27.

54. Сюков В.В., Кочетков Д.В., Кочерина Н.В., Чесноков Ю.В., Бёрнер А., Ловассер У. Выявление QTL, определяющих количественные признаки у яровой пшеницы в условиях Среднего Поволжья. Вестник Саратовского госагроуниверситета им. НИ Вавилова. 2012;(10):91-4

55. Толковый словарь по общей и молекулярной биологии, общей и прикладной генетике, ДНК-технологии и биоинформатике. Том 2. М.: Академкнига, Медкнига; 2008. с. 308.

56. Уоддингтон К.X. Морфогенез и генетика. М.: Мир; 1964.

57. Уоддингтон K.X. Основные биологические концепции. В кн.: На пути к теоретической биологии. М.: Мир; 1970. с. 11-38.

58. Хакен Г. Тайны природы. Синергетика: учение о взаимодействии. Пер. с нем. АР Логунова. - М.; Ижевск: Ин-т компьютер. исслед.; 2003. 319 с.

59. Химия верности. Поиск. 2013;(24):23.

60. Чадов Б.Ф. Эпигенетическая феноменология у условных мутантов Drosophila melanogaster: морфозы и модификации. В кн. Эпигенетика. Новосибирск: Наука СО РАН; 2013. c. 500-33.

61. Чесноков Ю.В., Почепня Н.В., Бёрнер А., Ловассер У., Гончарова Э.А., Драгавцев В.А. Эколого-генетическая организация количественных признаков растений и картирование локусов, определяющих агрономически важные признаки у мягкой пшеницы. Доклады Академии наук. 2008;418(5):1-4.

62. Чесноков Ю.В., Почепня Н.В., Козленко Л.В., Ситников М.Н., Митрофанова О.П., Сюков В.В., Кочетков Д.В., Ловассер У., Бёрнер $A$. Картирование QTL, определяющих проявление агрономически важных и хозяйственно ценных признаков у яровой пшеницы в различных экологических регионах России. Вавиловский журнал генетики и селекции. 2012;16(4/2):970-86.

63. Чураев Р.Н. О синтезе эпигенов. Препринт ИЦиГ СО АН СССР. Новосибирск; 1981. $35 \mathrm{c}$.

64. Чураев Р.Н. Прикладные аспекты кон- 
цепции эпигенов. Журнал общей биологии. 1982;43(1):79-87.

65. Шабанов Д. Парамутациями не ограничимся. Компьютерра. 2006;(23).

66. Энгельгардm B.A. Интегратизм - путь от простого к сложному в познании явлений жизни. Вопросы философии. 1970;(11):103-15.

67. Эпигенетика растений: Сборник научных трудов. Составители СИ Малецкий и ЕВ Левитес. Новосибирск: ИЦиГ СО РАН; 2005. 374 с.

68. Юданова С.С. Миксоплоидия клеточных популяций сахарной свеклы и ее связь с репродуктивными признаками. Дисс... канд. биол. наук. СПб.: ВИР; 2004. 126 с.

\section{Общий список литературы/References}

1. Anokhin P.K. Uzlovye Voprosy Teorii Funktsionalnykh Sistem. Moscow: Nauka; 1980. (In Russ.)

2. Arshinov V.I., Budanov V.G. [The role of synergetics in formulating of a new picture of the World]. In: Vyzov Poznaniyu. Strategii Razvitiya Nauki v Sovremennom Mire. Moscow: Nauka, 2004. 386 p. (In Russ.)

3. Astaurov B.L. Nasledstvennost i Razvitiye. Moscow: Nauka; 1974. 359 p. (In Russ).

4. Baranov V.S., Baranova Ye.V., Ivashenko T.Ye., Aseyev M.V. Genom Cheloveka i Geny Predraspolozhennosti. (Vvedeniye v Reproduktivnuyu Meditsinu). Saint Petersburg: Intermedika; 2000. (In Russ.)

5. Belousov L.V. [Morphogenesis, morphomechanics, and genome]. Vestnik VOGiS, 2009;13(1):29-35. (In Russ.)

6. Bogdanova Ye.D., Makhmudova K.Kh. Epigenetika Myagkoi Pshenitsy. Almaty; 2012. 106 p. (In Russ.)

7. Vavilov N.I. [Critical review of the modern status of genetic theory of breeding of plants and animals]. In: Vavilov NI. Zakon Gomologicheskikh Ryadov v Nasledstvennosti i Izmenchivosti. Leningrad: Nauka; 1987. p. 224-246. (In Russ.)

8. Vavilov N.I. Izbrannye Trudy Tom 5. Moscow-Leningrad; 1965. p. 275. (In Russ.)

9. Vanyushin B.F. [Materialization of epigenetics, or small changes with big consequences]. Khimiya i Zhizn 2004;(2):32-37. (In Russ).

10. Vasilyev A.G. Epigeneticheskye Osnovy Fenetiki: Na Puti k Evolutsionnoy Meronomii. Yekaterinburg; 2005. 640 p. (In Russ.)

11. Galitskiy V.A. [A hypothesis about the mechanism of the initiation of de novo DNA methylation by small RNA and of allelic exclusion]. Tsitologiya. 2008;50(4):277-86. (In Russ.)

12. Golubovsky M.D. Vek Genetiki: Evolutsia Idey i Ponyatiy. Saint Petersburg: Borey Art; 2000. 262 p. (In Russ.)

13. Grishko N.N., Delone L.N. Kurs Genetiki. Moscow: Selkhozgiz; 1938. 354 p. (In Russ.)

14. Gustaffson A. [Vavilov and parallel variability]. In: Genetika i Blagosostoyanye Chelovechestva. Moscow: Nauka; 1981. p. 40-53. (In Russ.)

15. Dawkins R. The Selfish Gene. Oxford: Oxford University Press; 1976.

16. Dragavtsev V.A., Sakharov V.I. [On a method of statistical analysis of long-term modifications in plants populations]. Zhurnal Obshey Biologii. 1972;(6):733-9. (In Russ.)

17. Dragavtsev V.A., Tsilke R.A., Reyter B.G. et $a l$. Genetica Priznakov Produktivnosti Yarovykh Pshenits v Zapadnoi Sibiri. Novosibirsk: Nauka SO AN; 1984. 230 p. (In Russ.)

18. Dragavtsev V.A., Litun P.P., Shkel N.M., Nechiporenko N.N. [A model of eco-genetic control of the quantitative characters of plants]. Doklady AN SSSR. 1984;274;(3):720-3. (In Russ).

19. Dragavtsev V.A. [A new method of genetic analysis of polygenic quantitative characters of plants]. In: Identifitsirovannyi Genofond Rasteniy i Selektsiya. Saint Petersburg: VIR; 2005. p. 20-35. (In Russ.)

20. Dragavtsev V.A. [The problems of filling the gaps between genes and characters in modern breeding]. Izvestiya RGAU-MSHA. 2009;(2):110-22. (In Russ.)

21. Dragavtsev V.A., Makarova G.A., Kochetov A.A., Kocherina N.V., Mirskaya G.V., Sinyavina N.G. [Some tasks of agrophysical securing of breeding technologies for eco-genetic increasing of productivity and yield of plants]. Agrofizika. 2011;(1):14-22. (In Russ.)

22. Dragavtsev V.A. [The eco-genetic organization of quantitative characters of plants and the theory of selection indexes]. In: Ekologicheskaya Genetika Kulturnykh Rasteniy. Krasnodar: VNII Risa; 2012. p. 1231-50. (In Russ.)

23. Dragavtsev V.A. [Lessons from the evolution of plant genetics]. Biosfera. 2012;4(3): 251-62. (In Russ.)

24. Dragavtsev V.A. [How to aid in sating the humanity]. Biosfera. 2013;5(3):279-90. (In Russ.)

25. Drize Yu. [From genome to proteome]. Poisk. 2014;(52):6. (In Russ.)

26. Zhuchenko A.A. [The genetic nature of adaptive potential of cultivated plants]. In: Identifitsirovannyi Genofond Rasteniy i Selektsia. Saint Petersburg: VIR; 2005, p. 36-101. (In Russ.)

27. Inge-Vechtomov S.G. [Yeast prions and the central dogma of molecular biology]. Vestnik RAN. 2000. 70(4);299-306. (In Russ.)

28. Kononkov P.F. Ocherk o Razvitii Biologii i Selskohoziaystvennykh Nauk V Sovetskiy Period. Moscow: Rossiyskiy Universitet Druzhby Narodov: 2007. 82 p. (In Russ.)

29. Korochkin L.I. Biologia Individualnogo Razvitiya. Moscow: Izdatelstvo MGU; 2002. 264 p. (In Russ.)

30. Kocherina N.V., Dragavtsev VA. Vvedenie v Teoriyu Ekologo-Geneticheskoi Organizatsii Poligennykh Priznakov Rasteniy i Teoriyu Seektsionnykh Indeksov. Saint Petersburg: AFIDon Bosko: 2008. 87 p. (In Russ.)

31. Kuznetsov V.V., Dmitriyeva G.A. Fiziologiya Rasteniy. Moscow: Izdatelstvo Abris; 2011. 784 p. (In Russ.)

32. Kuhn T. The Structure of Scientific Revolutions. Chicago: Univ. Chicago Press; 1962.

33. Kackser G. [Kinetic models of development and heredity]. In: Modelirovaniye v Biologii. Moscow: Inostrannaya Literatura; 1963. p. 42-64. (In Russ.)

34. Lavrov S.A., Mavpodiev Ye.V. [Epigenetic inheritance of characters and its possible role in 
plans microevolution]. Zhurnal Obschey Biologii. 2003;64(5):403-20. (In Russ.)

35. Lipton $B$. Umnye Kletki: Biologiya Ubezhdenii. Izdatelstvo Sofiya; 2011: 224 p. (In Russ.)

36. Lobashov M.E. Genetika $2^{\text {nd }}$ Ed. Leningrad: LGU; 1967. (In Russ.)

37. Maletskiy S.I., Melentyeva S.A. Tatur IS, Yudanova SS. Maletskaya EI. [Conservation of hybrid vigor in the apozygotic progeny of sugar beet]. Vestnik NAN Belarusi Agronomicheskiye Nauki. 2013;1:65-72. (In Russ.)

38. Maletskiy S.I., Roik N.V., Dragavtsev V.A. [The third variability, the types of heredity and the reproduction of plant seeds]. Selskokhoziaystvennaya Biologiya. 2013;(5):3-29. (In Russ.)

39. Maletskiy S.I. [Geometrical code of life by V. Vernadsky]. Vestnik Ukrainskogo Obschestva Genetikov i Selektsionerov. 2013;11(2):321-48. (In Russ.)

40. Markel A.L. [Physiological genetics]. Vavilovskiy Zhurnal Genetiki i Selektsii. 2014;18(1):112-24. (In Russ.)

41. Odum E.P. Ecology. New York: Holt, Rinehart and Winston; 1963.

42. Panshin B.A. [Breeding of sugar beet]. In: Teoreticheskiye Osnovy Sekektsii Rasteniy Tom 3. Moscow-Leningrad: Gosselkhozizdat; 1937. p. 439-482. (In Russ.)

43. Ratner V.A. Genetika, Molekulyarnaya Kibernetika. Lichnosti i Problemy. Novosibirsk: Nauka; 2002. 172 p. (In Russ.)

44. Rakhman M.M., Dragavtsev V.A. [The new approaches to prediction of plant heterosis]. Selskokhoziaystvennaya Biologiya. 1990;(1):3-12. (In Russ.)

45. Rekombinantnye Molekuly: Znacheniye Dlya Nauki i Praktiki. Moscow: Mir; 1980. (In Russ.)

46. Riger $R$, Mikhaelis A. Geneticheskiy i Tsitogeneticheskiy Slovar. Moscow: Kolos; 1967. $607 \mathrm{p}$.

47. Rozenberg G.S. [Holism + reductionism: two roads to the temple]. Vestnik RAN. 2014;84(9):830833. (In Russ.)

48. Savel'ev S.V. Izmenchivost' i Genialnost'. Moscow; 2012. (In Russ.)

49. Sverdlov Ye.D. [DNA in the cell: from molecular icon to the problem of what is life]. Vestnik RAN. 2003;73(6):497-505. (In Russ.)

50. Sverdlov Ye.D. [Does biological reductionism pass away? Then what is next?]. Vestnik RAN. 2006;(8):707. (In Russ.)

51. Szent-Gyorgyi A. Introduction to a Submolecular Biology. N.Y.-L.: Academic Press; 1963.

52. Stent G. Molecular genetics: An introductory narrative. San Francisco: W.H. Freeman \& Co; 1971. $650 \mathrm{p}$

53. Strunnikov V.A. [The third variability]. Priroda. 1989;(2):17-27. (In Russ.)

54. Siukov V.V., Kochetkov D.V., Kocherina N.V., Chesnokov Yu.V., Borner A., Lovasser U. [Detection of QTL determining quantitative characters of spring wheat under Middle Volga conditions]. Vestnik Saratovskogo Gosagrouniversiteta Imeni NI Vavilova. 2012;(10):91-94. (In Russ.)
55. Tolkovyi Slovar po Obshey i Molekulyarnoy Biologii, Obshey i Prikladnoy Genetike, DNKtekhnologii i Bioinformatike Tom 2. Moscow: Akademkniga, Medkniga; 2008. 308 p. (In Russ.)

56. Waddington K.H. Morfogenez i Genetika. M.: Mir; 1964. (In Russ.)

57. Waddington K.H. [The main biological concepts]. In: Na Puti k Teoreticheskoy Biologii Moscow: Mir; 1970. p. 11-38. (In Russ, translated from: Towards Theoretical Biology.)

58. Haken H. Erfolgsgeheimnisse der Natur Synergetik: Die Lehre vom Zusammenwirken. Deutsche Verlags-Ansalt GmbH, 1992.

59. [Chemistry of fidelity]. Poisk. 2013;(24):23 (In Russ.)

60. Chadov B.F. [Epigenetic phenomenology of conditional mutants of Drosophila melanogaster: morphosis and modifications]. In: Epigenetika. Novosibirsk: Nauka SO RAN; 2013. p. 500-33. (In Russ.)

61. Chesnokov Yu.V., Pochepnya N.V., Borner A., Lovasser U., Goncharova E.A., Dragavtsev V.A. [Eco-genetic organization of quantitative characters of plants and mapping of loci determining the agronomycally-important characters of soft wheat]. Doklady Akademii Nauk. 2008;418 (5):1-4. (In Russ.)

62. Chesnokov Yu.V., Pochepnya N.V., Kozlenko L.V., Sitnikov M.N., Mitrofanova O.P., Syukov V.V., Kochetkov D.V., Lovasser U., Borner A. [Mapping of QTL determining the agronomicallyimportant characters of spring wheat in different ecological regions of Russia]. Vavilovskiy Zhurnal Genetiki i Selektsii. 2012;16(4/2):970-86. (In Russ.) 63. Churaev R.N. [About synthesis of epigenes]. Preprint of Institute of Cytology and Genetics of the Siberian Branch of Academy of Sciences of the USSR. Novosibirsk; 1981. 35 p. (In Russ.)

64. Churaev R.N. [The applied aspects of epigenetic conception]. Zhurnal Obschey Biologii 1982;43(1):79-87. (In Russ.)

65. Shabanov D. [Being not limited by paramutations]. Computerra. 2006;(23). (In Russ.)

66. Engelgardt V.A. Integratism: a way from the simple to the complicated in comprehending life phenomena. Voprosy Filosofii. 1970;(11):103-115. (In Russ.)

67. Epigenetika Rasteniy: Sbornik Nauchnikh Trudov. Sostaviteli: S.I. Maletskiy, E.V. Levites. Novosibirsk: Institute of Cytology and Genetics of the Siberian Branch of the Russian Academy of Sciences; 2005. 374 p. (In Russ.)

68. Yudanova S.S. Miksoploidiya Kletochnykh Populyatsiy Sakharnoy Svekly i Yeyo Svyaz s Reproduktivnymi Priznakami. Ph. Theses. Saint Petersburg: VIR; 2004. 126 p. (In Russ.).

69. Alberts B., Bray D., Lewis R.M., Roberts K., Watson J. Molecular Biology of the Cells. New York Garland; 1994. 369 p.

70. Alleman M., Doctor J. Genomic imprinting in plants: observation and evolutionary implications. Plant Mol Biol. 2000;43(2-3):147-61.

71. Bastow R., Mylue J..S, Lister C., Lippman Z., Martienssen R.A., Dean C. Vernalization requires epigenetic silencing of FLC by histone methylation. Nature. 2004;427:164-7. 
72. Borner A., Schulman T., Furste A., Costel H., Lethold B., Roder M.S., Weber W.E. Mapping of quantitative trait loci determining agronomic important characters in hexaploid wheat. Theor Appl Genet. 2002;105:921-36.

73. Brenton R.G., Kaur A., Gunning D., Zipursky S.L., Rowen .L, Clements J.C. The organization and evolution of the Dipterian and Hymenopterian Down syndrome cell adhesion molecule (Dscam) genes. RNA. 2004; 10:1499-506.

74. Celotto A.M., Graveley B.R. Alternative splicing of the Drosophila Dscam pre-mRNA temporally and spatially regulated. Genetics. 2001;159:599-608.

75. Cleland R.E. Oenothera Cytogenetics and Evolution. N.Y.: Acad. Press; 1972. 370 p.

76. Danchin E., Charmantier A., Champagne F. Beyond DNA: integrating inclusive inheritance into an extended theory of evolution. Nature Rev Genet. 2011;12:475-86.

77. Dragavtsev V.A. Algorithms of an Eco-genetic Survey of the Gene Fund and Methods of Creating the Varieties of Crop Plants for Yield, Resistance and Quality. Saint Petersburg: VIR; 2002. 41 p.

78. Dragavtsev V.A., Dragavtseva Ye.V. Mechanisms sustaining displacement of quantitative trait dominance in spring wheat of various geographical regions. Russian Journal of Genetics. 2011;47(5):53-7.

79. Durrant $A$. The environmental induction of heritable change in Linum. Heredity. 1962;17:27-61.

80. Greval S.S., Moased D. Heterochromatin and epigenetic control of gene expression. Science. 2003;301:798-802.
81. He Y., Michaels S.D., Amasino R.V. Regulation of flowering time by histone acetylation. Science. 2003; 302:1751-4.

82. Hurd P.J. The era of epigenetic. Brief Funct Genomics. 2010;9:425-8.

83. Jablonka E., Lamb M.J. The epigenome in evolution: beyond the modern synthesis. Vestnik VOGiS. 2008; 2:242-54.

84. Moose S.P., Mumm R.H. Molecular plant breeding as the foundation for XXI century crop improvement. Plant Physiol. 2008;147:969-77.

85. Nurse P. The end of understanding. Nature. 1997;387:657.

86. Meyer P., editor. Plant Epigenetics. Leeds: University of Leeds; $2005.320 \mathrm{p}$

87. Richards A.J. Plant Breeding System. London-N.Y.: Chapman \& Hall; 1997, p. 298-333.

88. Rosenberg A. Darwinian Reductionism, or How Stop Worrying and Love Molecular Biology. Chicago: Univ. Chicago Press; 2006. 272 p.

89. Schmitz R.J. The secret garden: Epigenetic alleles underlie complex traits. Science. 2014;343:1082-3.

90. Sung S., Amasino R.M. Vernalization and epigenetics: how plants remember winter. Curr Opin Plant Biol. 2004;7:4-10.

91. The Limits of Reductionism in Biology. London: Ciba Foundation; 1997.

92. Thomas W.T.B. Prospects for molecular breeding of barley. Ann Appl Biol. 2003;142:1-12.

93. Sinclair T.R. Purcell LC. Is a physiological perspective relevant in a "genocentric" age? J Exper Botany 2005;56:2777-82.

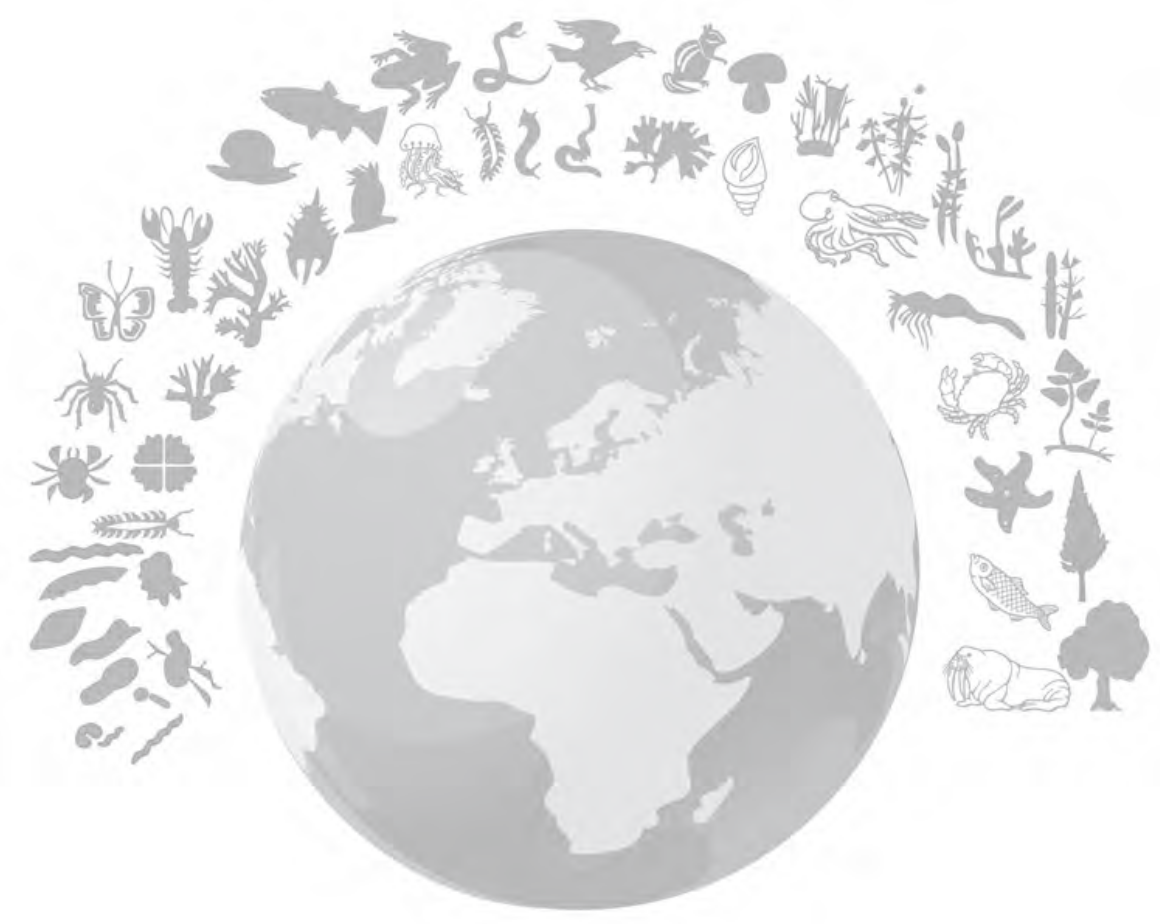

